\title{
Einladung zur Mitgliederversammlung der DRG am Freitag, den 31. Mai 2019, 8 Uhr
}

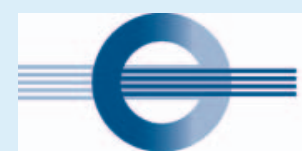

\section{DEUTSCHE RÖNTGENGESELLSCHAFT}

Gesellschaft für medizinische Radiologie e.V.

Zur ordentlichen Mitgliederversammlung der Deutschen Röntgengesellschaft - Gesellschaft für Medizinische Radiologie e. V. (DRG), am Freitag, den 31. Mai 2019, von
8:00 bis 9:00 Uhr im Congress Centrum Leipzig (CCL) im Raum Röntgen, lädt der Vorstand der DRG die Mitglieder der DRG hiermit herzlich ein.
Die Einlasskontrolle erfolgt über den Kongressausweis. Entsprechend der Satzung der DRG können an der Mitgliederversammlung nur Mitglieder teilnehmen, deren Beitragskonto für 2019 ausgeglichen ist.

Im Namen des Vorstandes

Prof. Dr. Stefan O. Schönberg (Präsident) 